\title{
Autonomia copilului de vârstă mică. Repere pedagogice. Book review
}

\author{
Gina Florentina Tudorache•, Mihaela Badea ${ }^{\bullet}$
}

By

\section{Genoveva Farcaș}

Iași: Editura Polirom, 2019

\section{ISBN: 978-973-46-7888-4, 227 pages}

In the increasingly pronounced context of social change caused by digital technology, globalization and multiculturalism, more and more educational policies have focused their goals in the direction of developing autonomy lately. Seen as a pillar of adaptation in the face of ambiguity and uncertainty, dimensions of contemporary society, the schools of the 21st century pay special attention to identifying those fundamental skills that young people need for academic and social success.

In the frequently prominent circumstances of new technologies, the learning process resizes its format, both in terms of content, learning mechanisms and the

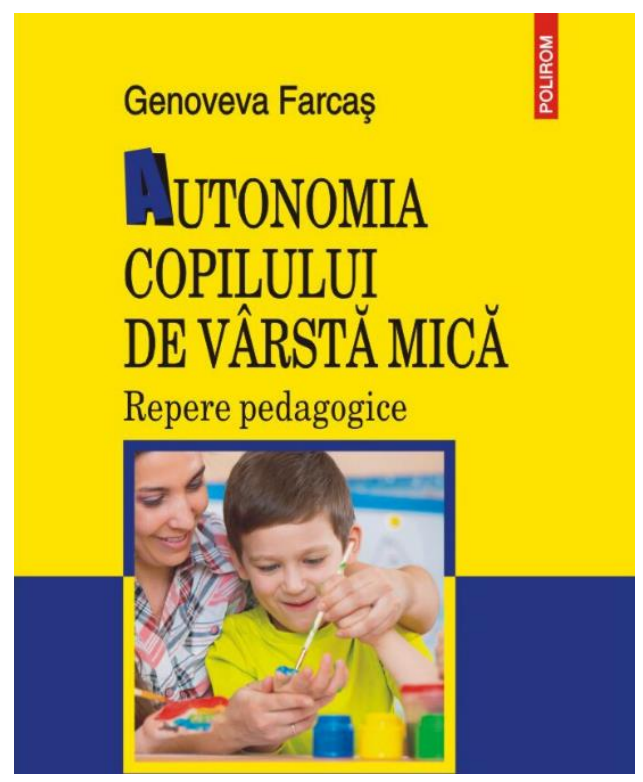
role played by the teacher. Thus, under the influence of the virtual environment that offers unlimited access to information, success in education is no longer brought by the reproduction of ideas, but consists in the ability to use them in concrete life situations. At the same time, curiosity, learning through discovery, interaction, cooperation, collaboration, and experimentation are the new dimensions of the learning process. Among these coordinates, the role of the teacher shifts its focus from transmitting knowledge, to guiding students in the optimal direction of learning, to stimulating motivation and developing their abilities.

Thus, the educational approaches must be adapted to the contemporary reality, bringing useful strategies for the development of autonomy, configured as a transversal competence and inherent to our days. In this sense, the development of creativity, critical thinking, development of initiative, decision making, problem solving have become the main directions that support this desideratum.

\footnotetext{
- Primary School Teacher, Ph.D., Bărcănești School, Petroleum - Gas University of Ploiești, Romania, e-mail: gina.tudorache16@yahoo.com

- Assoc. Prof. Ph.D., Petroleum-Gas University of Ploiești, Romania, e-mail: $\underline{\text { mbadea@upg-ploiesti.ro }}$
} 
Developed in a theoretical-reflective, but also practical-applicative manner, this book is a valuable tool both for researchers in the field of education and students, teachers, and parents concerned with the formation of children's autonomous behaviors. The author's rich experience in the field of educational sciences research, well combined with the vast list of bibliographical references, gives this work a prestigious title. The readable perspective of the content presentation attracts the reader, maintaining his interest by well-balanced intertwining of theoretical and practical-applied guidelines. Thus, the paper presents guiding aspects for building and supporting young children's autonomous behavior, as well as the values of a broader framework for their integration.

In the context of the increasing emphasis of pedagogical research on the development of autonomy, seen as the general purpose of the educational act, this paper offers a significant contribution in the educational literature for early education. The novelty element is given by the outlining, in a pragmatic way, of the necessary steps to build child autonomy at an age when addiction and self-determination coexist.

Being structured in six chapters, the book presents fundamental landmarks in the preschool child's formation of autonomy, starting from "Autonomie și educație. Repere conceptuale" / "Autonomy and education. Conceptual landmarks". Thus, a series of definitions of autonomy are outlined, a concept analysed later in relation to freedom, identity, responsibility, independence and dependence. A series of philosophical, sociological, but also psychological perspectives on autonomy emphasize the differences that remove the synonymous sign with these terms, beyond the correlations provided. Finally, it is concluded that autonomy is that competence of the human individual manifested through self-determination, the expression and responsible fulfillment of their own decisions, their assumption and internalization. Analyzing in detail one of the basic concepts of the paper, the chapter is the starting point in addressing this issue.

Also, the paper presents "Teorii și modele explicative privind formarea comportamentelor autonome" / "Theories and explanatory models on the formation of autonomous behaviours", investigating the theories of development and their implications in educational actions meant to form the child's autonomy. Thus, following the development of autonomous behavior especially in the early period, the chapter illustrates points of view discussed by both classical and contemporary theories, such as: the socioconstructivist theory of L.S. Vygotsky, E. Erikson's psychosocial theory, J. Bowlby's theory of attachment, A. Bandura's theory of social-cognitive learning, and E. L. Deci and R. M. Ryan's theory of self-determination. The chapter addresses an inherent part of the issue, as the psychological models presented offer relevant values on the educability of behaviors, especially in early ontogenesis.

With the same accuracy, the trajectory "De la pedagogia autonomiei la educația pentru autonomie" / "From the pedagogy of autonomy to the education for autonomy" is described, starting from the approach of autonomy from the perspective of the Montessori pedagogical system, from the perspective of Célestin Freinet, Adolphe Ferrière, but also from the perspective of the Step-by-Step project. Finally, education for 
autonomy is presented, indicating the pedagogical principles, as well as ways of action for the formation of autonomous behaviour. Therefore, the chapter complements the general subject of the book by presenting some pedagogical concepts of great significance that have as educational principles the assurance of the child's freedom and independence of action, in accordance with his particularities and interests.

At the same time, the book brings to attention aspects of "Dezvoltării comportamentelor autonome ale copiilor de vârstă preșcolară în mediul familial" / "Development of preschool children' autonomous behaviours in the family environment", presenting the specifics of autonomous behaviours in the early age, the importance of the family environment in building autonomous behaviours and ways to support child autonomy. On the one hand, the whole chapter emphasizes the responsibility of the family in the development of the pre-schooler's autonomous conduct, as the first social link with which he interacts; on the other hand, it highlights the role of the kindergarten environment that engages the child in formal and non-formal learning situations.

In addition, the author considers "Dezvoltarea comportamentelor autonome ale copiilor prin curriculum preșcolar"/ "The development of children's autonomous behaviours through the preschool curriculum", presenting aspects of early education on the past-present axis, as well as the formative-educational values of playful activities. The chapter offers an x-ray of international and national policies in early education, bringing to attention the changes in the area of teaching practice in Romania.

Reflecting on the construction of child's autonomy in the early period, the paper concludes with an experimental study on the development of personal and social autonomous behaviours of preschool children aged 5-6 years. The study draws attention to the importance of family and kindergarten environments in the transition from support to independence, from guidance to autonomy. Thus, the role of educators and parents in supporting children's autonomy through educational interventions related to their particularities is emphasized.

In an extensive representation of the issue related to the development of kindergarden children's autonomous behaviour, the work of Genova Farcas provides benchmarks for both beginners and experienced researchers in the present mirage of modern educational actions. Through the theoretical and practical-applied approaches of this pedagogical topic of maximum interest nowadays, the paper outlines elucidations regarding the educational practices that support the construction of autonomy, which gives it the merit for a wider dissemination in the field. Leveraging the theoretical and practical-applied evidence presented in a balanced and cohesive way, we recommend this paper to educators, students in preparation for preschool education, as well as parents interested in forming children's autonomous behaviour. 